RADOVI

UDK 7.025:615.12(497.523Varaždin)

Zavoda za znanstveni rad

Pregledni članak

HAZU Varaždin

Review

VLADANKA MILOŠEVIĆ

Primljeno: 01. 02. 2019.

Hrvatski restauratorski zavod

Prihvaćeno: 17. 05. 2019.

vmilosevic@h-r-z.hr

DOI: $10.21857 /$ mzvkptzoz9

IVANA PEŠKAN

Konzervatorski odjel u Varaždinu

ivana.peskan@min-kulture.hr

BERNARDA RATANČIĆ

Hrvatski restauratorski zavod

bratancic@h-r-z.hr

PETRA UGLEŠIĆ

Hrvatski restauratorski zavod, puglesic@h-r-z.hr

\title{
NOVE KONZERVATORSKE SPOZNAJE O OSLIKANOJ FRANJEVAČKOJ LJEKARNI U VARAŽDINU
}

Uslijed recentnog propadanja svodne slike Ivana Krstitelja Rangera u jednoj od prostorija prizemlja zgrade nekadašnjeg nemoćišta franjevačkog samostana u Varaždinu, $\mathrm{Hr}$ vatski restauratorski zavod je 2013. godine započeo konzervatorsko-restauratorska istraživanja i radove obnove s namjerom utvrđivanja, a potom i otklanjanja uzroka oštećenja. Ovim radom prezentiraju se nove spoznaje o povijesnoj slojevitosti franjevačke ljekarne, utvrđeni elementi zahvata iz sredine 18. stoljeća, koji ujedno predstavljaju $i$ najvrjedniju fazu oblikovanja, te intervencije kojima se nastojalo stvoriti uvjete za početak restauratorskih radova na svodnom osliku. Uz činjenicu da su istraživanja cijele zgrade i dalje u tijeku, neka pitanja su za sada još ostala otvorena, no i postojeća saznanja definiraju ovaj spomenik kao biser varaždinske barokne umjetnosti. 


\section{UVOD}

Vrlo loše stanje svodnog oslika najveće prostorije prizemlja zgrade nekadašnjeg franjevačkog nemoćišta u Varaždinu bilo je povod za angažiranje Hrvatskog restauratorskog zavoda 2013. godine. Ocijenjeno je da oslik ubrzano propada te da je nužno poduzeti zahvate za sprječavanje daljnje razgradnje slikanog sloja i stvoriti uvjete za restauratorsku obnovu svodne slike.

Provedena su povijesna i arhivska istraživanja nadopunjena rezultatima sondiranja, laboratorijskim analizama, mjerenjima vlage i kontinuiranim praćenjem stanja oslika. Obzirom na otežane uvjete, odnosno trenutnu zauzetost i nepristupačnost gornjih etaža građevine gdje se nalazi depo Državnoga arhiva u Varaždinu, istraživanja su do sada bila ograničena na podrum i prizemlje. Dramatično stanje slikanoga sloja je potaknulo istovremeno odvijanje preventivnih zaštitnih građevinskih radova i konzervatorskih istraživanja. Unatoč tome, omogućen je uvid u djelić povijesti građevine, kao i nove spoznaje o najznačajnijoj fazi uređenja iz sredine 18. stoljeća.

O povijesti franjevačkog nemoćišta s ljekarnom pisali su već najraniji kroničari franjevačkoga reda - o. Apolinar Braničković i Janko Barlé. ${ }^{1}$ Obzirom na važnost djelovanja franjevačke ljekarne u kontekstu pregleda razvoja ljekarništva u Varaždinu, brojni su radovi koji su se njome bavili s tog aspekta. ${ }^{2} \mathrm{O}$ nemoćištu piše i o. Emanuel Hoško u djelu o povijesti organizirane brige za bolesnu i staru subraću unutar franjevačkog reda. ${ }^{3}$ Najopsežniji rad o povijesti franjevačkoga samostana u Varaždinu pa tako i njegovog nemoćišta i ljekarne je knjiga

1 Apolinar BRANIČKOVIĆ, „Crtice iz prošlosti franjevačkog samostana u Varaždinu“, Franjevci u Varaždinu, Glasnik sv. Franje, 1, Varaždin, 1927, 23-25, 34-36.; Janko BARLÉ, „Ranarnici i ljekarnici iz franjevačkog reda“, Hrvatski liječnički zbor, Liječnički vijestnik, 3, Zagreb, 1907, 66-69.

2 Lujo PIHLER, „Stare varaždinske ljekarne i ljekarnici“, Farmaceutsko društvo Hrvatske, Farmaceutski glasnik, 7, Zagreb, 1951, 220-225, 269-277; Dragutin FELETAR, „Prinos povijesti ljekarništva u sjeverozapadnoj Hrvatskoj", Podravina: časopis za multidisciplinarna istraživanja, 2, Samobor, 2003, 2351; Gustav PIASEK, „Prilog povijesti franjevačke ljekarne u Varaždinu“, Farmaceutsko društvo Hrvatske, Farmaceutski glasnik, 37, Zagreb, 1981, 476-478; Gustav PIASEK i Martina PIASEK, „Varaždinsko zdravstvo u 17. stoljeću“, Institut za medicinska istraživanja Hrvatske akademije znanosti i umjetnosti u Zagrebu, Arhiv za higijenu rada i toksikologiju, 55, Zagreb, 2004, 25-34; Ivan DAMIŠ, „Prisutnost franjevaca (OFM) i njihovo djelovanje u prošlosti Varaždina“, 800 godina slobodnog i kraljevskog grada Varaždina 1209. - 2009., Zbornik radova s međunarodnog znanstvenog skupa održanog 3. i 4. prosinca 2009. godine u Varaždinu, Hrvatska akademija znanosti i umjetnosti Zavod za znanstveni rad Varaždin, Grad Varaždin, Varaždinska županija, gl. ur. Miroslav ŠıCEL, Slobodan KAŠTELA, Zagreb-Varaždin, 2009., 97-108; http://www.hdft.hr/ljekarnistvo-u-franjevackim-samostanima-provincije-svetih-cirila-i-metodija/ (14. veljače 2014.)

3 Emanuel HOŠKO, „Briga hrvatskih franjevaca za bolesne članove od XVII. do XIX. stoljeća“, Hrvatsko znanstveno društvo za povijest zdravstvene kulture, Acta medico-historica Adriatica, 2, Rijeka, 2011, 265-278. 
franjevca o. Paškala Cvekana. ${ }^{4}$ Varaždinski povjesničar Krešimir Filić je 1923. godine „otkrio“ svodnu sliku u prizemlju nemoćišta te je atribuirao Ivanu Krstitelju Rangeru, ${ }^{5}$ a njegovu atribuciju su preuzeli i drugi istraživači. Kasniji tekstovi čiji naglasak je bio na svodnoj slici su se bavili ikonografskim i stilskim analizama oslika, ${ }^{6}$ a najveći doprinos „čitanju“ ikonografskog prikaza dala je Marija Mirković kroz niz radova. ${ }^{7}$ Noviji radovi su obrađivali varaždinski oslik u kontekstu Rangerovog opusa i općenito unutar baroknog slikarstva, ${ }^{8}$ a opsežni rad o građevinskoj genezi i povijesti zgrade prema poznatim povijesnim i arhivskim podacima su objavile Bernarda Ratančić i Vladanka Milošević. ${ }^{9}$

\section{GRAĐEVINSKI RAZVOJ ZGRADE NEKADAŠNJEG NEMOĆIŠTA S LJEKARNOM}

Odluka o osnivanju infirmarije, odnosno nemoćišta za stare i bolesne redovnike u sklopu zagrebačkog i varaždinskog franjevačkog samostana, donesena je na prvom svečanom sastanku Provincije sv. Ladislava u Ormožu 1662. godine. ${ }^{10}$

4 Paškal CVEKAN, Djelovanje franjevaca u Varaždinu, Zagreb, 1978.

5 Krešimir FILIĆ, Franjevci u Varaždinu: poviest franjevačke crkve i samostana: o 700-godišnjici dolazka franjevaca u Varaždin, vlast. nakl., Varaždin, 1944.

6 Hrvoje TARTALJA, „Freske Ivana Rangera u franjevačkoj ljekarni u Varaždinu“, Pliva, Saopćenja, 12, Zagreb, 1969., 85-90; Tomislav ĐURIĆ, Barokno slikarstvo Ivana Rangera, vlast. nakl., Varaždin, 1976; Ernest FIŠER, Barokni iluzionizam Ivana Rangera, Kajkavsko spravišče, Zagreb, 1977.

7 Marija MIRKOVIĆ, „Barokni program Rangerove stropne slike u franjevačkom samostanu u Varaždinu“, Gradski muzej Varaždin, Godišnjak gradskog muzeja Varaždin, 5, Varaždin, 1975, 97-106; Marija MIRKOVIĆ, „Ikonološki programi zidnih slika u samostanskim ljekarnama hrvatskih pavlina i franjevaca“, Hrvatski liječnički zbor, Podružnica Rijeka, Acta Facultatis medicae Fluminensis, 3-4, Rijeka, 1992, 119-129; Marija MIRKOVIĆ i Janko BELAJ, „Varaždin. Franjevačka ljekarna, oslikana 1750.“, Otvorena nebesa Ivana Krstitelja Rangera = Offenes Himmelsgefilde von Johann Baptist Ranger: izložba o 250. godišnjici slikareve smrti, Lepoglava, lipanj - rujan 2003., Turistička zajednica grada Lepoglave, gl. ur. Ernest FIŠER, Lepoglava, 2003., 56-61; Marija MIRKOVIĆ i Janko BELAJ, „Mali biseri. Varaždin. Franjevački samostan, ljekarna“, Czvet szveteh - zidno slikarstvo Ivana Krstitelja Rangera = Blumen der Heiligen - Wandmalerei von Johannes Baptist Ranger: druga izložba o 250. godišnjici slikareve smrti (1753), Lepoglava, svibanj - rujan 2004., Turistička zajednica grada Lepoglave, ur. Marija MIRKOVIĆ, Janko BELAJ, Lepoglava, 2004., 58-60; Marija MIRKOVIĆ i Janko BELAJ, „Varaždin: Marija je Nebeska Ijekarna", Likovna poruka Ivana Krstitelja Rangera = Bildliche Botschaft von Johannes Baptist Ranger: treća izložba o 250. godišnjici slikareve smrti (1753), Lepoglava, ljeto 2006., Turistička zajednica grada Lepoglave, ur. Janko BELAJ, Marija MIRKOVIĆ, Lepoglava, 2006., 62-69.

8 Mirjana REPANIĆ BRAUN, Barokno slikarstvo u Hrvatskoj franjevačkoj provinciji sv. Ćirila i Metoda, Institut za povijest umjetnosti, Zagreb, 2004; Sanja CVETNIĆ, Ikonografija nakon Tridentskoga sabora i hrvatska likovna baština, FF Press, Zagreb, 2007.

9 Bernarda RATANČIĆ i Vladanka MILOŠEVIĆ, „Prilog poznavanju povijesti franjevačke ljekarne u Varaždinu“, Portal: godišnjak Hrvatskog restauratorskog zavoda, 7, Zagreb, 2016, 193-208.

10 Arhiv franjevačkog samostana u Varaždinu (dalje AFVŽ), II. sv, 1700-1760, Decisiones Diffinitoriales concernentes residentiaum Franciscano-Varasdinensem, ex provinciae matricula excerpta (dalje Decisiones Diff.); K. FILIĆ, n.dj., 68. 
Varaždinsko je nemoćište najprije bilo uređeno u prostorijama samostanskih krila, da bi krajem sedamdesetih godina 17. stoljeća Kapitul reda istaknuo nužnost izgradnje zasebne zgrade nemoćišta. ${ }^{11}$ Gradnja je započela oko 1678. godine na zemljištu koje je ustupio grad Varaždin pod uvjetom da nova ljekarna bude otvorena i za javnost. ${ }^{12}$

Arhivski dokumenti iz 18. stoljeća navode šture podatke o postojanju starijeg zida (fundo civitatis) na mjestu današnje zgrade. ${ }^{13}$ No, o točnijem izgledu tih građevnih struktura u ranijem razdoblju nema više podataka. Postojeća je zgrada podignuta uz zapadno samostansko krilo. Izvorno se sastojala od prizemlja i dva kata, a natkrivenim prolazom je bila povezana sa samostanom.

Uspješnost poslovanja nemoćišta s ljekarnom, koja je djelovala u periodu od nešto više od sto godina, bilo je promjenjivo. U vrijeme pojedinih upravitelja pljačkan je potreban materijal i pronevjereni su veći iznosi novaca, pa je zbog toga nemoćište stavljeno pod upravu franjevačkog sindika ili varaždinskoga gvardijana. Sredinom 18. stoljeća, odnosno nakon što je 1736. godine upraviteljem imenovan otac Wolfgang Frauendienst, ${ }^{14}$ nemoćište $s$ ljekarnom je odvojeno od uprave samostana i djelovalo je kao zasebna institucija pod nazivom Rezidencija svetog Didaka. ${ }^{15} \mathrm{U}$ tom razdoblju dolazi do veće obnove i preuređenja cijele zgrade, prilikom čega je u oslikavanju svoda jedne prostorije prizemlja bio uključen znameniti pavlinski slikar Ivan Krstitelj Ranger. lako u arhivskim izvorima zasad nisu pronađene potvrde o njegovu angažmanu, njegov je umjetnički izraz jasan i prepoznatljiv. ${ }^{16} \mathrm{O}$ opsegu cijele barokne obnove nema detaljnijih pisanih podataka, no pojedine je zahvate moguće detektirati na temelju provedenih konzervatorsko-restauratorskih istraživanja.

Franjevačka je ljekarna zatvorena 1772. godine odlukom kraljice Marije Terezije. ${ }^{17}$ Inventar je rasprodan, a prostorije su preuređene. Godine 1786 . s radom je prestalo i nemoćište, a od tada zgrada je služila raznim namjenama. Početkom 20. stoljeća u njoj je uređeno đačko sjemenište, zbog čega je 1904. godine uz juž-

11 J. BARLÉ, $n$. dj., 66.; K. FILIĆ, $n$. dj., 69; P. CVEKAN, $n$. dj., 143.

12 P. CVEKAN, $n . d j ., 143,148$.

13 AFVŽ, Decisiones Diff.

14 P. CVEKAN, n. dj. 150.

15 Isto, 152.

16 Artur SCHNEIDER, „Popisivanje i fotografijsko snimanje umjetničkih spomenika godine 1939.“, Jugoslavenska akademija znanosti i umjetnosti, Ljetopis za godinu 1938/1939., Zagreb, 52, 1940, 184; K. FILIĆ, $n$. dj., 82; M. MIRKOVIĆ, „Barokni program Rangerove stropne slike u franjevačkom samostanu u Varaždinu“, 98.; M. MIRKOVIĆ, „Ikonološki programi zidnih slika u samostanskim ljekarnama hrvatskih pavlina i franjevaca", 124.

17 P. CVEKAN, n. dj., 152. 
no pročelje dograđen stubišni rizalit. ${ }^{18}$ Idućih godina su se za potrebe sjemeništa također odvijali određeni zahvati: stari drveni podovi u hodnicima prvog i drugog kata zamijenjeni su betonskim podlogama, a zatim su izmijenjeni i stropovi. U prizemlju pak, uz prostoriju s oslikanim svodom, porušeni su pregradni zidovi kako bi se dobila velika prostorija za refektorij. ${ }^{19}$ Kasnije je na gornjim etažama došlo i do rušenja i zidanja novih pregradnih zidova, uređivanja sanitarnih čvorova i drugih prilagodbi, a godine 1940 . je dograđen treći kat. ${ }^{20}$ Nakon Drugog svjetskog rata, zgrada je postala đački dom.

\section{RANIJE KONZERVATORSKE INTERVENCIJE}

Što se događalo sa zgradom nemoćišta u drugoj polovici 20. stoljeća, nije sasvim jasno. Pedesetih je godina prof. Ferdo Ladika držao u najmu prostoriju s oslikanim svodom, no ne zna se jesu li već u tom razdoblju provedeni neki restauratorski zahvati. ${ }^{21}$ Početkom sedamdesetih godina stanje oslika je pregledao direktor Restauratorskog zavoda Hrvatske prof. Branko Lučić, koji je utvrdio da je najveći problem kapilarna vlaga koja se penje čak do visine od 1,80 m. ${ }^{22}$

Zgrada je u to vrijeme bila dana na korištenje Odjelu za povijest farmacije JAZU-a te se pokušalo riješiti problem vlage putem elektroosmotskog sustava isušivanja. Međutim, došlo je do prekida financiranja programa pa sustav nije bio održavan i nije postigao željene rezultate. U međuvremenu, u zgradu je useIjen tadašnji Historijski (danas Državni) arhiv u Varaždinu, čiji depo se i danas nalazi na gornja tri kata. Ogromna količina arhivskog materijala stvara veliki pritisak na donje etaže i uzrokuje jako opterećenje na zidanu i svodnu konstrukciju prizemlja.

Vrlo loše stanje svodne slike potaknulo je daljnje intervencije - krajem sedamdesetih godina provedena su preliminarna ispitivanja oslika s izradom dokumentacije postojećeg stanja, ${ }^{23}$ a 1989. godine je izveden novi sustav elektroosmotskog isušivanja prostorije. Iz sačuvane dokumentacije može se iščitati da su

18 Nacrti za prigradnju stubišnog rizalita se nalaze u: Državni arhiv u Varaždinu (dalje: DAVŽ), fond Građevinska dokumentacija Varaždina i okolice 1755.-1945. (dalje: GD 1755.-1945.), inv. br. 5934.

19 O svim radovima na zgradi nekadašnjeg nemoćišta vidi: K. FILIĆ, $n$. dj., 69, 82; B. RATANČIĆ, V. MILOŠEVIĆ, $n$. dj., 199.

20 DAVŽ, GD, 1755.-1945. Potpisan ing. Valentin Morandini, 18. svibnja 1940. godine.

21 Ladika u zahtjevu za najam prostora navodi da je prostorija jako zapuštena - zidovi su nagriženi vlagom, pod je truo, oslik je oštećen i djelomično otpao. Ministarstvo kulture - Uprava za zaštitu kulturne baštine, Topografska zbirka (dalje MK-UZKB / SA - TOZ), grad Varaždin, 311-1956.

22 Arhiv Restauratorskog zavoda Hrvatske (dalje: ARZH), br. dosjea 36, 1971., br. dok. 1.

23 Ispitivanja je provodio Restauratorski zavod Hrvatske. ARZH, br. dosjea 36, 1978., br. dok. 4. 
tada zidovi premazani akvatrilom i injektirani stonosalom, ${ }^{24}$ no nije bilo poznato kolika je površina bila obuhvaćena tim zahvatima. Ponovno, zbog prestanka financiranja, planirani sustav isušivanja nije proveden do kraja. Izrađena je dokumentacija sustava drenaže i odvodnje površinskih voda i radovi su izvedeni prema projektu, no bez konzervatorskog i stručnog nadzora.

\section{OPIS I ANALIZA ZATEČENOGA STANJA GRAĐEVINE I ZIDNOG OSLIKA}

Neredovito provođene konzervatorske intervencije te nerješavanje uzroka problema i slabo održavanje cijele zgrade uvjetovali su pojavu brojnih oštećenja na samoj građevini, a posebice na svodnoj slici. Današnja zgrada sastoji se od podrumske etaže, prizemlja, tri kata i potkrovlja. Izvorno, bila je za jedan kat niža te nije imala stubišni rizalit. Tlocrtna organizacija se ponavlja po etažama - duž južnog pročelja je dugački hodnik, dok se u sjevernom dijelu nižu prostorije koje u pravilu imaju ulaz iz hodnika (slika 1). Podrumska etaža je površinom manja od ostalih i razlikuje se po tlocrtnom rasporedu. Današnji prilaz u podrum je kroz vrata na sjevernom pročelju i ne postoji direktna komunikacija između podruma i prizemlja.
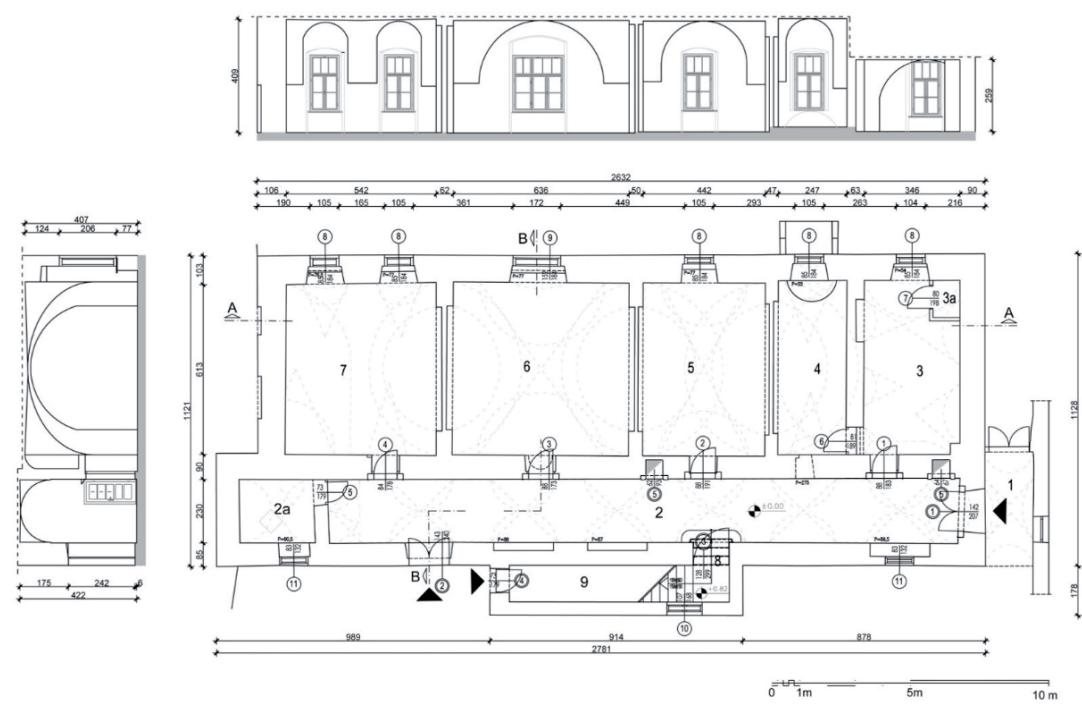

Slika 1. Tlocrt i presjeci prizemlja nekadašnjeg franjevačkog nemoćišta (izradio HRZ, 2018.)

24 ARZH, br. dosjea 36, 1989., br. dok. 9, 10. 
Prostorija s oslikanim svodom je druga prostorija prizemlja gledano sa zapada. Ima približno kvadratni tlocrt, ulaz joj je na južnom zidu, a osvijetljena je jednim velikim prozorom sa sjevera. Svod je zidan opekom kao križno-bačvasti koji se petama upire u četiri kuta prostorije. Zidna slika je detaljno elaborirani i simbolički bogat prikaz sv. Marije kao Nebeske ljekarne, okružene simbolima četiriju elemenata, personifikacijama kontinenata, prikazima ljekovitih biljaka i korisnih svojstava, te dobima ljudskog života. ${ }^{25}$ Specifičnost ovoga prikaza u odnosu na ostale iz Rangerova opusa je korištenje poganskih motiva i personifikacija, odnosno ispreplitanje sakralnih i antičkih elemenata. Takva je kombinacija umjetnikova izričaja zasigurno bila moguća radi dvojne namjene ljekarne, obzirom da je ona bila otvorena i za javnost, a ne samo za franjevce. Stoga su prirodni elementi prikazani kroz antičke likove i povezani sa starozavjetnim scenama. Svi su prikazi ujedinjeni u Mariji kao Kraljici svemira koja na grudima nosi simbol Svetoga Trojstva (slika 2).

Prilikom prvog pregleda građevine 2013. godine, uočena je jaka degradacija slikanoga sloja, posebice na jugozapadnoj peti svoda. Povijesne fotografije toga detalja ukazuju na rapidno propadanje slike u odnosu na ranija razdoblja. Primjerice, na fotografijama nastalima u periodu od proteklih 50 godina, vidljiva su mjestimična oštećenja, no slikani prikaz bio je još čitljiv (slika 3). Fotografije zatečenoga stanja iz 2013. godine pokazuju pak potpuni gubitak slikanoga sloja, čak i pripremnog crteža u većoj mjeri, dok je na podu ispod pete bila vidljiva sipina (slika 4).

25 Detaljnu ikonografsku analizu prikaza vidi u: M. MIRKOVIĆ, „Barokni program Rangerove stropne slike u franjevačkom samostanu u Varaždinu“, 100. 
VLADANKA MILOŠEVIĆ i surad.: Nove konzervatorske spoznaje o oslikanoj franjevačkoj ljekarni u Varaždinu

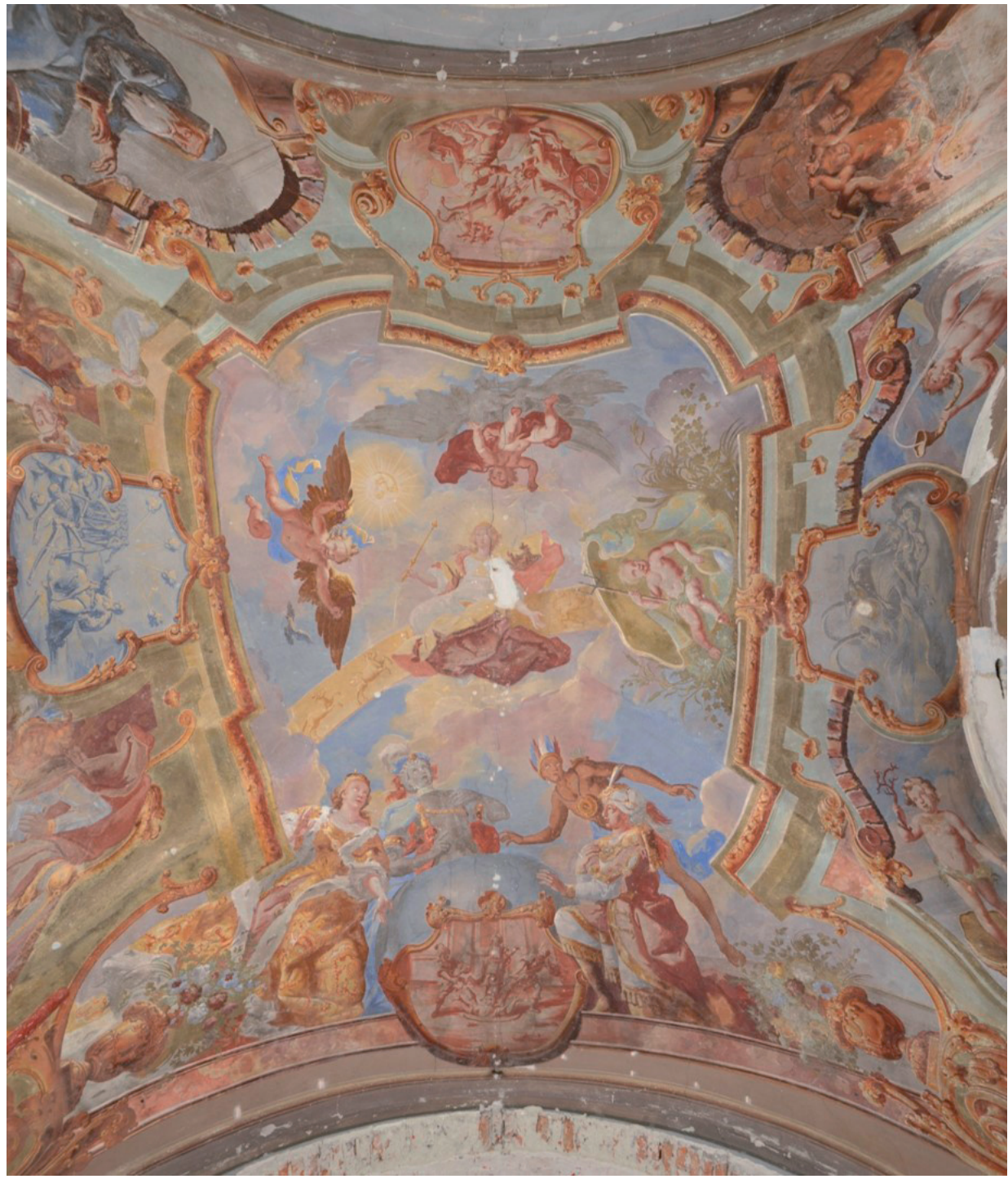

Slika 2. Svodna slika u prostoriji ljekarne (fototeka HRZ-a, N. Vasić, 2013.) 

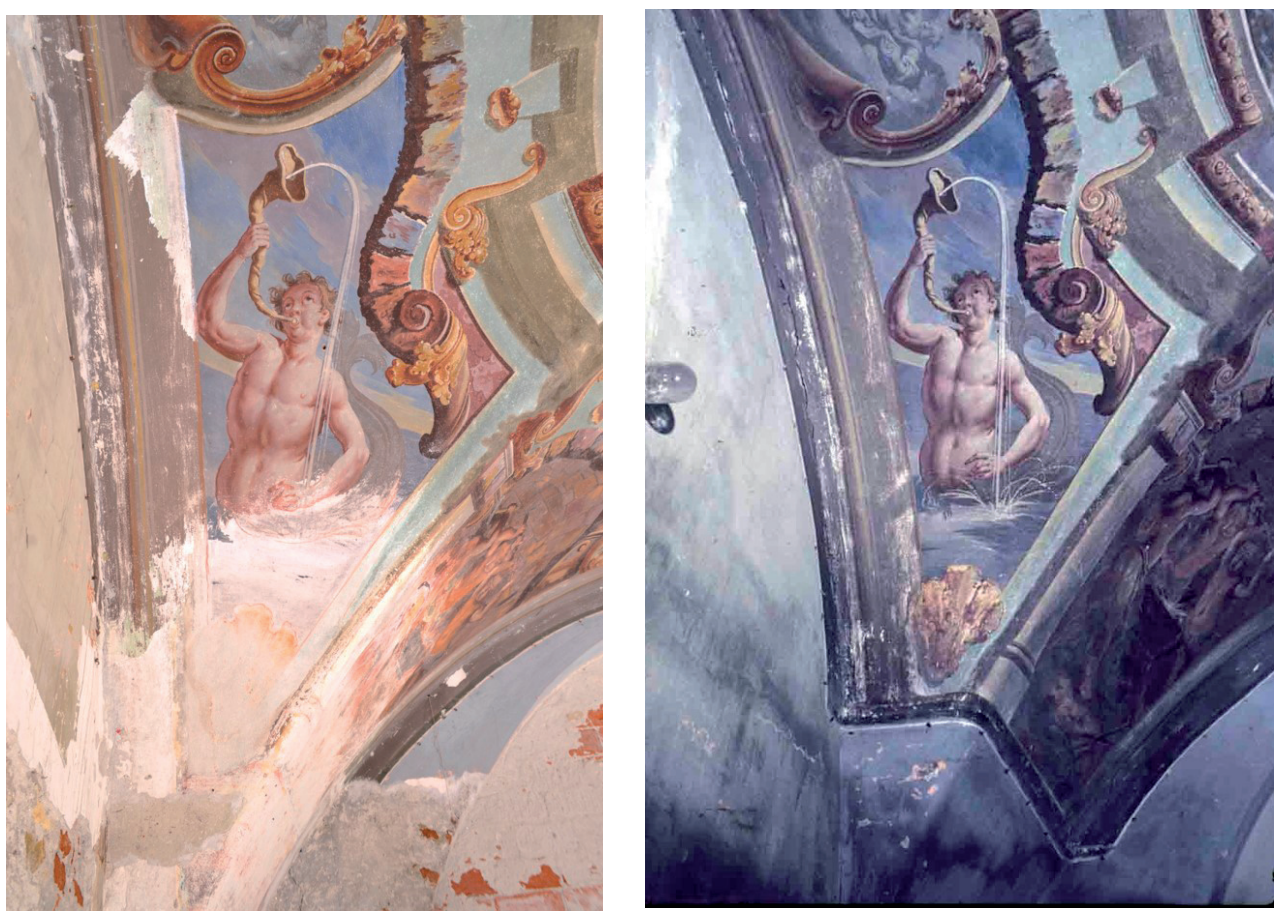

Slika 3. (L) Detalj oslika na jugozapadnoj svodnoj peti (fototeka RZH-a, I. Maroević, 1979.) Slika 4. (D) Detalj oslika na jugozapadnoj svodnoj peti 2013. godine (fototeka HRZ-a, J. Kliska, 2013.)

Na svodnoj površini bile su uočljive brojne pukotine, od kojih se najveća pruža točno po sredini svoda. Zatečena razina vlage u prostoru bila je vrlo visoka, najviše zbog neredovitog provjetravanja i neodržavanja te neuspješnih ranijih pokušaja sanacije vlage. Prostorija ljekarne i ostale prostorije prizemlja služile kao depo elemenata demontiranog glavnog oltara iz franjevačke crkve, dok je podrumski prostor bio zakrčen. Ukratko, cijeli prostor je bio u jako lošem stanju i bilo je nužno brzo intervenirati radi popravljanja mikroklimatskih uvjeta.

\section{PROVEDENA KONZERVATORSKA ISTRAŽIVANJA I PRELIMINARNI RADOVI ZAŠTITE}

U svrhu utvrđivanja i uklanjanja štetnih utjecaja i stvaranja povoljnijih uvjeta, 2013. godine započeta su preliminarna konzervatorsko-restauratorska istra- 
živanja. ${ }^{26}$ Istraživanjima je prethodila izrada geodetske situacije i 3D lasersko skeniranje sjevernog i južnog pročelja građevine, s izradom jedinstvenog i georeferenciranog 3D modela te izradom arhitektonskih nacrta postojećeg stanja prizemlja i podruma.

Terenska su istraživanja bila ograničena na prostor hodnika i oslikane prostorije prizemlja, a obuhvaćala su sondiranje građe, žbuka i naliča, utvrđivanje stanja kamena i laboratorijska ispitivanja (mjerenje vlage, analiza soli, granulometrijski sastav žbuka, petrografska analiza kamena, rendgenska difrakcija, analiza pigmenata, određivanje starosti drvene građe metodom AMS-14C). Rezultati istraživanja su ukazali na ranije drugačije formate prozorskih otvora hodnika i zidnih niša u kojima su smješteni. Također je utvrđeno da je današnji glavni ulaz u zgradu na južnom zidu hodnika formiran naknadno, što je otvorilo pitanje izvornog položaja glavnih vrata i njihovog odnosa s istočnim vratima. Nadalje, u prostoru hodnika su pronađeni tragovi starijih žbukanih slojeva, kao i izvornog crnog obojenja kamenih portala.

Izvršen je pregled i detaljna analiza postojećeg stanja svodne slike. Oslik je izveden u fresco tehnici, s detaljima izvedenima secco, s vidljivim granicama dnevnica. U sklopu restauratorskih analiza iscrtana je i grafička dokumentacija, obavljene su probe čišćenja i fiksiranja oslika te su uzeti uzorci za laboratorijska ispitivanja. Utvrđene su pukotine na svodu, brojna mehanička oštećenja, tamne mrlje koje ukazuju na prisutnost plijesni, površinske nečistoće, pulverizacija pigmenata, osipanje i ljuskanje slikanog sloja, mjestimični preslici, prisutnost naknadnih žbuka i druga oštećenja (slika 5).

Najveći je problem, uz visoku koncentraciju vlage u prostoru, predstavljala pojava soli na zidovima, zbog čega su zaustavljeni daljnji restauratorski zahvati. Odlučeno je da prioritet bude uklanjanje štetnih utjecaja i stvaranje mikroklimatskih uvjeta povoljnih za početak restauratorskih radova na samom osliku. Laboratorijske analize ukazale su na izrazito visoke koncentracije nitrata i u manjoj mjeri sulfata od čega većina potječe iz postojeće cementne žbuke, hidroizolacijskog premaza (akvatril) i kemijskih sredstava (stonosal) kojima je zid injektiran prilikom ranijih pokušaja sanacije. U svrhu uklanjanja štetnih utjecaja otvorena je sonda u podu kod najoštećenijeg dijela svodnog oslika, odnosno u jugozapadnom kutu prostorije ljekarne. Utvrđeno je da nasip ispod postojećeg betonskog poda čini mokri riječni agregat te je odlučeno da se cijeli pod ukloni.

26 Istraživanja je vodila Vladanka Milošević, d.i.a, a radni tim su činili: dr. sc. Krasanka Majer Jurišić, Bernarda Ratančić, Ivana Drmić, Petra Uglešić, dr. sc. Domagoj Mudronja, Ivan Jengić, Natalija Vasić i Jovan Kliska. 


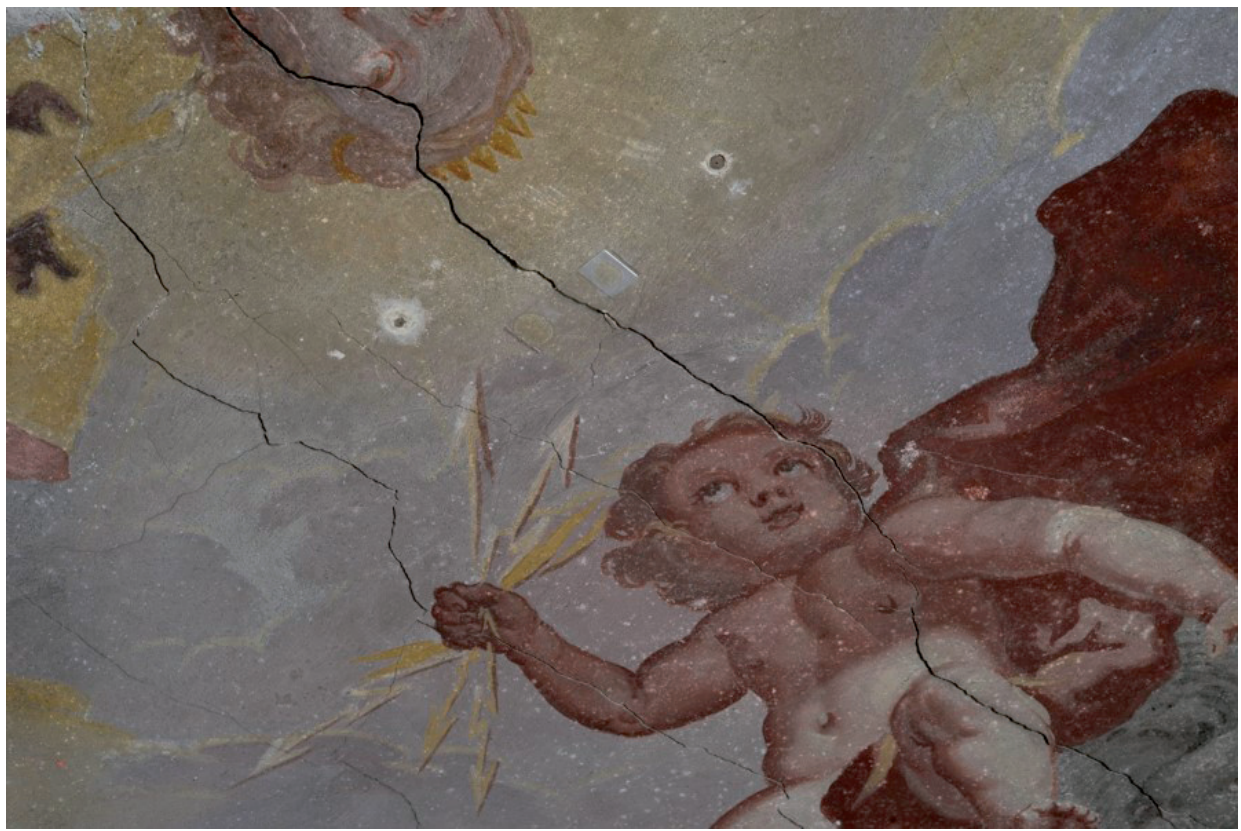

Slika 5. Detalj svodne slike s vidljivim pukotinama i oštećenjima slikanog sloja (fototeka HRZ-a, N. Vasić, 2013.)

Nakon uklanjanja betonskog poda i nasipa gornja ploha svoda podrumske prostorije ostavljena je da se prosuši nakon čega je premazana vapnom. Džepovi su zapunjeni laganim betonom u izvedbi odmaknutim od zidova (slika 6). Potom su uklonjeni slojevi cementne žbuke i akvatril premaza sa zidova hodnika prizemlja te podrumskih prostorija. Na ulazu u oslikanu prostoriju projektirano je i izvedeno novo vratno krilo kojim je omogućeno konstantno provjetravanje prostorije. 


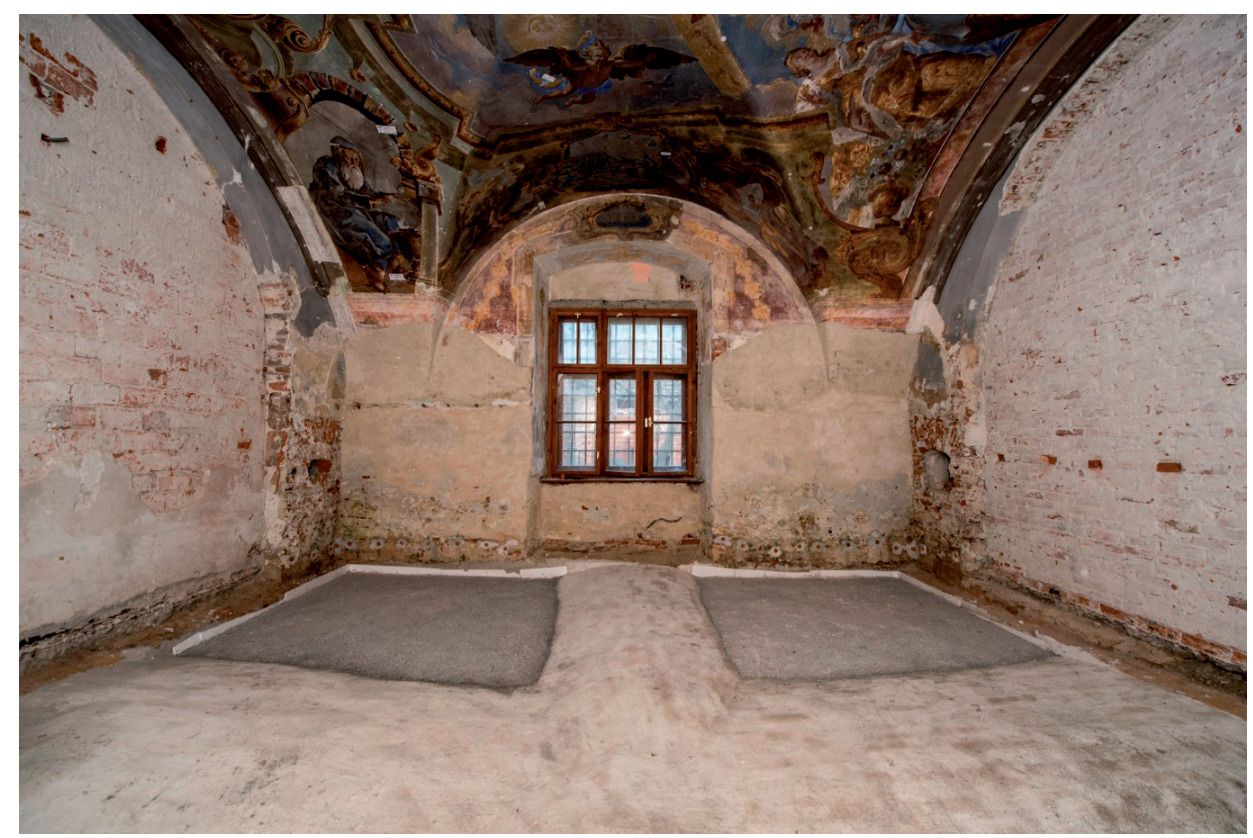

Slika 6. Prostorija ljekarne nakon uklanjanja betonskog poda i mokrog agregata i postavljanja laganog betona, pogled prema sjeveru (fototeka HRZ-a, N. Vasić, 2016.)

Iz zidova oslikane prostorije i hodnika prizemlja izvučene su zahrđale željezne elektrode koje su korodiranjem povećale svoj volumen i razarale strukturu zida. U prostoru hodnika prizemlja je uz unutrašnji (sjeverni) zid iskopan dugački rov u podu, kako bi se ispitao odnos između razine prizemlja i površinski manjeg podruma. Prilikom iskopavanja su utvrđeni tragovi najstarijeg drvenog stubišta prema podrumu. U podrumu su izvedene tri podne sonde kojima je utvrđeno da zidovi podruma danas nemaju temelje, vjerojatno zbog snižavanja razine poda prilikom uređenja podruma tijekom 20. stoljeća.

Svi navedeni pripremni radovi izvedeni su u cilju utvrđivanja i otklanjanja štetnih utjecaja, odnosno stvaranja povoljnih uvjeta za početak restauratorskih radova na svodnom osliku. Također, uklanjanjem velike količine novije površinske žbuke omogućen je uvid u strukturu zidova i svodova što je olakšalo definiranje građevinskih mijena, promjena otvora i drugih zahvata. 


\section{NOVE SPOZNAJE}

lako se u arhivskim podacima spominjao raniji zid ili građevina na mjestu postojeće, tek je na temelju provedenih istraživanja i preliminarnih zaštitnih radova bilo moguće definirati njegove elemente. Uklanjanjem površinske žbuke sa zidova zapadnih podrumskih prostorija detektiran je stariji povijesni sloj kamenih zidova, odnosno tragovi građevine na kojoj je podignuta postojeća zgrada.

Prema otkrivenim nalazima moguće je djelomično rekonstruirati faze izgradnje, odnosno definirati pojedine građevinske zahvate. Najstarijem građevnom sloju pripada veći dio podrumskih zidova, uključujući sjeverni i južni obodni te središnji (unutrašnji nosivi) zid. Istovjetna kamena građa sačuvana je u nivou prizemlja u visini od oko $110 \mathrm{~cm}$ od razine poda (slika 7). U zidu su utvrđene kvadratne rupe za drvene grede, što možda označava poziciju drvenog grednika. Istom građevnom sloju pripada pronađeno unutrašnje stubište između prizemlja i podruma, utvrđeno na krajnjem zapadnom dijelu hodnika uz sjeverni zid. Trenutno još nije moguće utvrditi točan izgled i namjenu tog starijeg objekta jer nisu istraženi svi temelji, zidovi i svodovi.

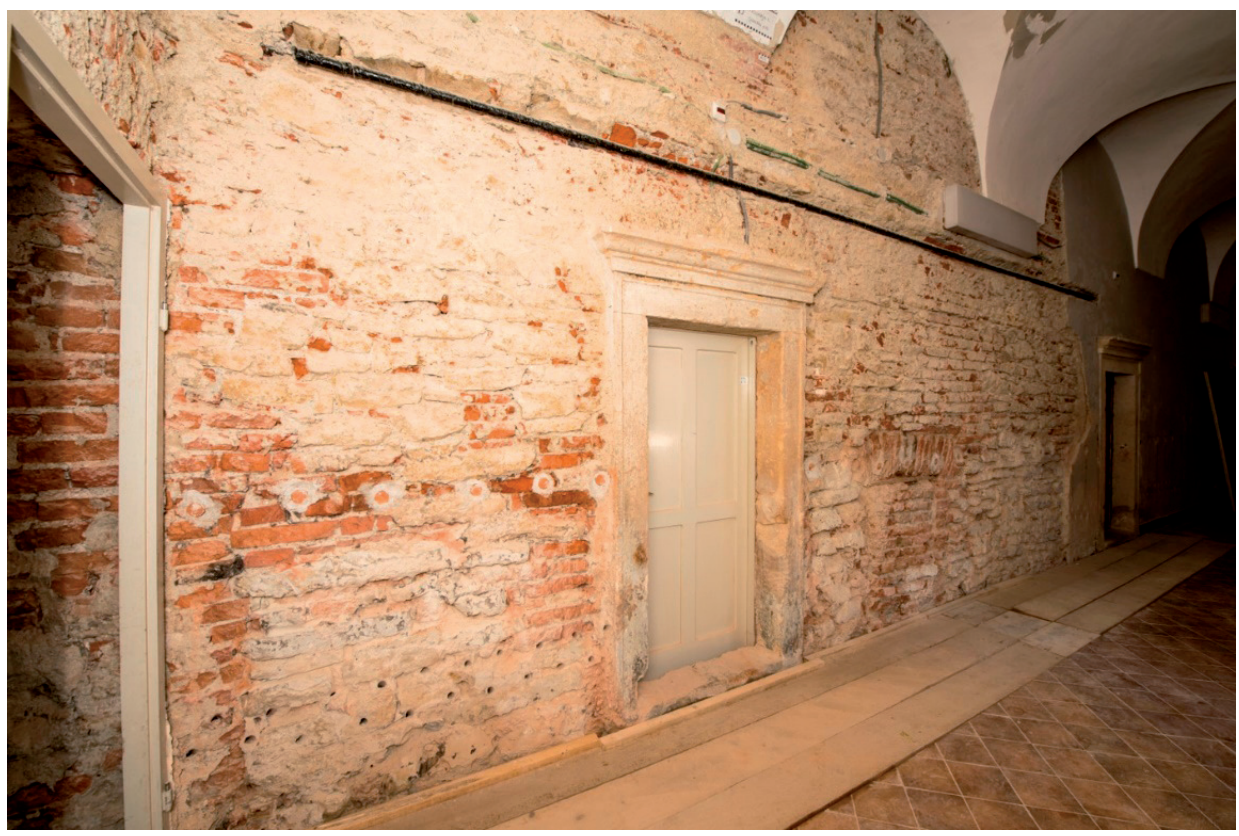

Slika 7. Sjeverni zid hodnika nakon uklanjanja cementne žbuke i akvatril premaza (fototeka HRZ-a, N. Vasić, 2016.) 
U drugoj građevinskoj fazi, koju možemo odrediti kao izgradnju nemoćišta 1676. godine, nad ranijim strukturama podignuta je današnja građevina. U kamenom zidu probijena su postojeća vrata prostorija lijevo i desno od ljekarne i na njih su postavljeni kameni profilirani okviri. Okviri su u toj fazi bili bojani crnim naličem, a crvenom bojom su bili označeni brojevi prostorija. $U$ istom razdoblju u hodniku su formirana ložišta i zidani dimnjaci. Tada je ukinuto stubište prema podrumu, a zid je nadograđen prema zapadu. Vertikalna komunikacija je izmaknuta, odnosno formirana je nova uz južni zid hodnika (slika 8). U istoj vertikali se nalazilo stubište prema katu. Južni zid hodnika bio je u toj fazi rastvoren otvorima drugačijeg formata od postojećih, moguće čak i otvorenim arkadama. Intervencije su u ovoj fazi bile izvedene uglavnom opečnom građom s manjim udjelom kamena.

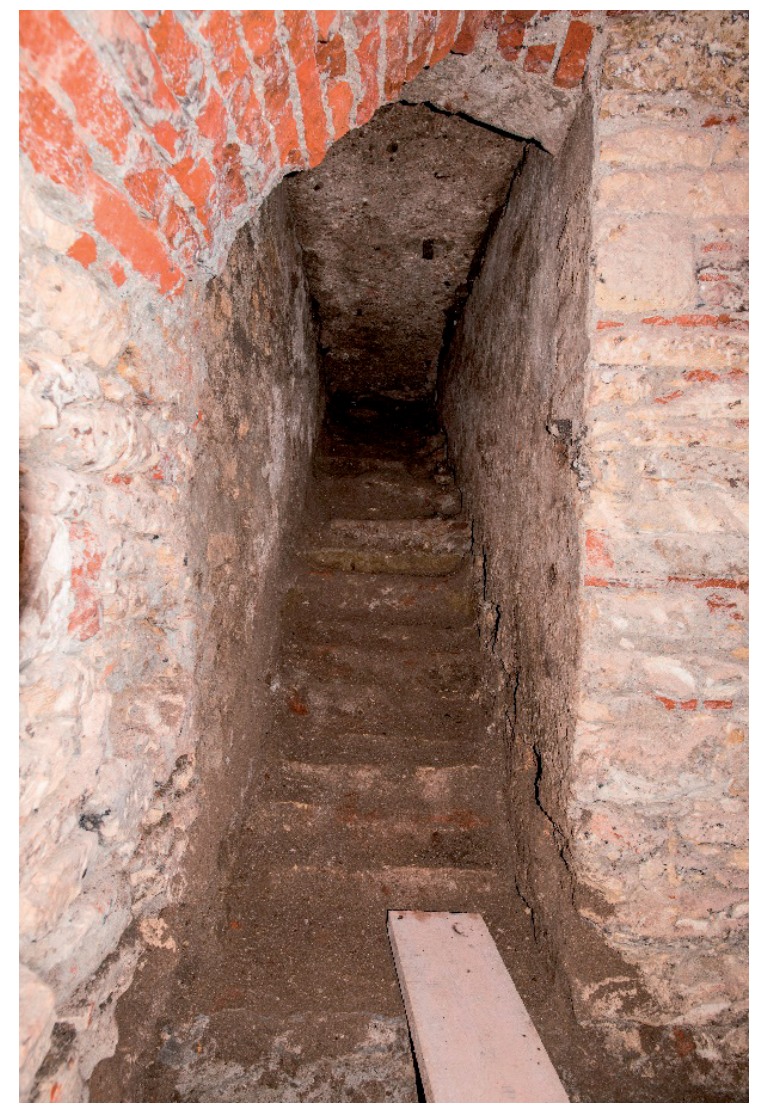

Slika 8. Stubište između podruma i prizemlja (fototeka HRZ-a, snimila N. Vasić, 2018.) 
Zazidano i neadekvatno očišćeno ložište pronađeno u zidu između krajnjih zapadnih prostorija, odnosno uz najoštećeniji dio svodne slike u jugozapadnom uglu, zasigurno je jedno od glavnih izvora štetnih utjecaja, koji su doveli do snažnog propadanja slikanog sloja upravo na tom mjestu (slika 9). Obzirom da njegovo postojanje prije nije bilo poznato, nije ga bilo moguće sanirati i ukloniti, što se planira budućim radovima.

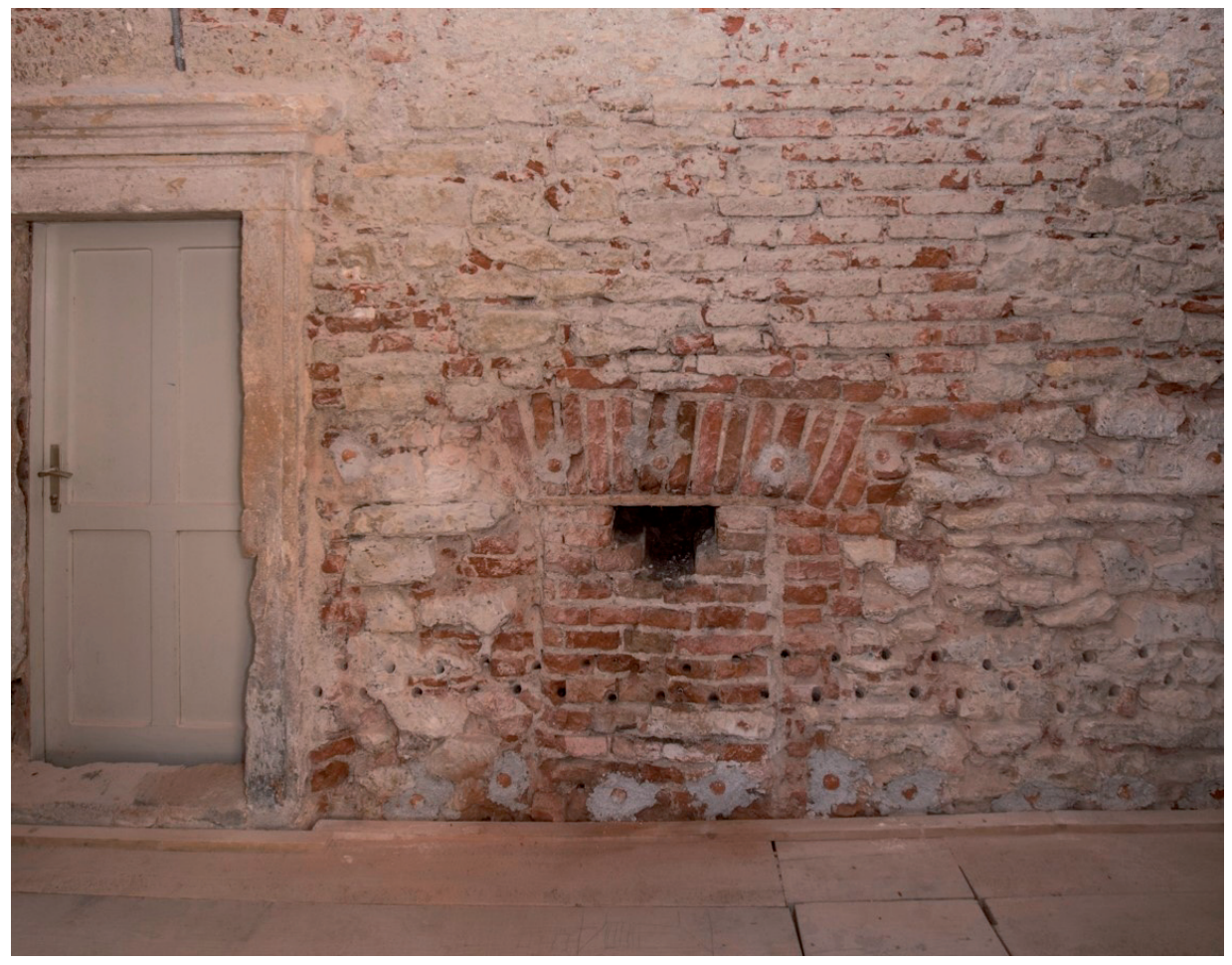

Slika 9. Zazidano ložište u sjevernom zidu hodnika prizemlja (fototeka HRZ-a, N. Vasić, 2017.)

Treću građevinsku fazu treba vezati uz konačno oblikovanje prostorije ljekarne, ostvareno obnovom sredinom 18. stoljeća. Nad postojećim ulazom u prostoriju, za razliku od susjednih, nema lučnog nadvoja formiranog u građi što ukazuje na njegovo naknadno otvaranje, a nepostojanje rasteretnog luka dovelo je do pucanja ravne grede kamenog nadvratnika. S ovog okvira izostaje i crni nalič utvrđen na ostalim okvirima što također ukazuje na njegovo kasnije postavljanje. Formiranje postojećih niša vrata i prozora oslikane prostorije treba datirati 
istovremeno s oslikavanjem prostorije, na što upućuje sačuvani oslik na bočnim stranicama niša otvora.

Tada se gradi postojeći križno-bačvasti svod prostorije, koji nije konstruktivno vezan uz južni zid prostorije. Nadalje, gradnja svoda je u koliziji s postojećom nišom na južnom zidu koja je prilikom uređenja prostorije bila zazidana. Postojanje te niše moguće ukazuje na raniju drugačiju namjenu ove prostorije kao kapele sv. Didaka, koja se spominje u arhivskim izvorima, a spomen na nju je očuvan i u nazivu Rezidencije tijekom obnove sredinom 18. stoljeća. Sv. Didak bio je franjevac koji se posvetio brizi za bolesne i nemoćne te je postojanje kapele posvećene njemu unutar bolnice vrlo vjerojatno, no zasada ipak nije moguće sa sigurnošću utvrditi gdje se ona nalazila. Istraživanjima je nadalje utvrđeno da je prostorija, u fazi kada je bila oslikana, bila povezana sa susjednom istočnom prostorijom i s njom je tvorila jedinstven prostor.

Sve dosadašnje pretpostavke i zaključci moraju se povezati s promjenama koncepcije prostora prizemlja koje još nisu jasno definirane. Naime, kao što je već bilo spomenuto, do sada provedena istraživanja i radovi izvedeni su primarno sa svrhom otklanjanja štetnih utjecaja na svodnu sliku, zbog čega su bila prostorno ograničena, a otegotna okolnost je i činjenica da je prostor u upotrebi. Tako zasada otvorena ostaju pitanja o izgledu izvornog stubišta prema gornjim etažama, o odnosu između pojedinih prostorija, o izvornoj poziciji glavnoga ulaza kao i o oblikovanju prostora hodnika prije izgradnje stubišnog rizalita.

\section{ZAKLJUČAK}

Provedena konzervatorsko-restauratorska istraživanja i izvedeni preliminarni radovi ispunili su svoju zadaću utvrđivanjem i smanjivanjem štetnih utjecaja na vrijedan Rangerov oslik. Otkriveno neočišćeno zazidano ložište i vlažni riječni agregat ispod betonskog poda mogu se definirati kao glavni „krivci“ za katastrofalno stanje zatečeno 2013. godine. Uspješnom dosadašnjom suradnjom Hrvatskog restauratorskog zavoda s nadležnim Konzervatorskim odjelom, braćom franjevcima kao vlasnicima i korisnicima te vanjskim suradnicima i izvođačima građevinskih radova, ostvaren je veliki pomak prema konačnom cilju programa, a to je početak restauratorskih radova na zidnom osliku i u konačnici njegovo predstavljanje i otvaranje javnosti. Zbog još uvijek prisutnih problema nužan je nastavak provođenja stručnog monitoringa mikroklimatskih uvjeta i određivanja metoda desalinizacije kao i nastavak planiranih istražnih i zaštitnih radova. Nadamo se da će saznanja stečena dosadašnjim i budućim istraživanjima omogućiti izradu i izvedbu cjelovitog projekta obnove zgrade nekadašnjeg nemoćišta u kojoj će se moći predstaviti bogata ostavština Male braće u Varaždinu. 


\section{LITERATURA}

1/ Arhiv franjevačkog samostana u Varaždinu, II. sv,. (1700.-1760.), Decisiones Diffinitoriales concernentes residentiaum Franciscano-Varasdinensem, ex provinciae matricula excerpta.

2/ Janko BARLÉ, „Ranarnici i ljekarnici iz franjevačkog reda“, Hrvatski liječnički zbor, Liječnički vijestnik, 3, Zagreb, 1907, 66-69.

3/ Apolinar BRANIČKOVIĆ, „Crtice iz prošlosti franjevačkog samostana u Varaždinu“, Franjevci u Varaždinu, Glasnik sv. Franje, 1, Varaždin, 1927, 23-25., 34-36.

4/ Paškal CVEKAN, Djelovanje franjevaca u Varaždinu, Zagreb, 1978.

5/ Sanja CVETNIĆ, Ikonografija nakon Tridentskoga sabora i hrvatska likovna baština, FF Press, Zagreb, 2007.

6/ Ivan DAMIŠ, „Prisutnost franjevaca (OFM) i njihovo djelovanje u prošlosti Varaždina“, 800 godina slobodnog i kraljevskog grada Varaždina 1209. 2009., Zbornik radova s međunarodnog znanstvenog skupa održanog 3. i 4. prosinca 2009. godine u Varaždinu, Hrvatska akademija znanosti i umjetnosti Zavod za znanstveni rad Varaždin, Grad Varaždin, Varaždinska županija, gl. ur. Miroslav ŠICEL, Slobodan KAŠTELA, Zagreb - Varaždin, 2009., 97-108.

7/ Tomislav ĐURIĆ, Barokno slikarstvo Ivana Rangera, vlast. nakl., Varaždin, 1976.

8/ Dragutin FELETAR, „Prinos povijesti ljekarništva u sjeverozapadnoj Hrvatskoj", Podravina: časopis za multidisciplinarna istraživanja, 2, Samobor, 2003., 23-51.

9/ Krešimir FILIĆ, Franjevci u Varaždinu, vlast. nakl., Varaždin, 1944.

10/ Ernest FIŠER, Barokni iluzionizam Ivana Rangera, Kajkavsko spravišče, Zagreb, 1977.

11/ Emanuel HOŠKO, „Briga hrvatskih franjevaca za bolesne članove od XVII. do XIX. stoljeća“, Hrvatsko znanstveno društvo za povijest zdravstvene kulture, Acta medico-historica Adriatica, 2, Rijeka, 2011, 265-278.

12/ Marija MIRKOVIĆ, „Barokni program Rangerove stropne slike u franjevačkom samostanu u Varaždinu“, Gradski muzej Varaždin, Godišnjak gradskog muzeja Varaždin, 5, Varaždin, 1975, 97-106.

13/ Marija MIRKOVIĆ, „Ikonološki programi zidnih slika u samostanskim ljekarnama hrvatskih pavlina i franjevaca", Hrvatski liječnički zbor, Podružnica Rijeka, Acta Facultatis medicae Fluminensis, 3-4, Rijeka, 1992, 119-129.

14/ Marija MIRKOVIĆ i Janko BELAJ, „Varaždin. Franjevačka ljekarna, oslikana 1750.", Otvorena nebesa Ivana Krstitelja Rangera = Offenes Himmelsgefilde 
von Johann Baptist Ranger: izložba o 250. godišnjici slikareve smrti, Lepoglava, lipanj - rujan 2003., Turistička zajednica grada Lepoglave, gl. ur. Ernest FIŠER, Lepoglava, 2003., 56-61.

15/ Marija MIRKOVIĆ i Janko BELAJ, „Mali biseri. Varaždin. Franjevački samostan, ljekarna", Czvet szveteh - zidno slikarstvo Ivana Krstitelja Rangera = Blumen der Heiligen - Wandmalerei von Johannes Baptist Ranger: druga izložba o 250. godišnjici slikareve smrti (1753), Lepoglava, svibanj - rujan 2004., Turistička zajednica grada Lepoglave, ur. Marija MIRKOVIĆ, Janko BELAJ, Lepoglava, 2004., 58-60.

16/ Marija MIRKOVIĆ i Janko BELAJ, „Varaždin: Marija je Nebeska ljekarna“, Likovna poruka Ivana Krstitelja Rangera = Bildliche Botschaft von Johannes Baptist Ranger: treća izložba o 250. godišnjici slikareve smrti (1753), Lepoglava, ljeto 2006., Turistička zajednica grada Lepoglave, ur. Janko BELAJ, Marija MIRKOVIĆ, Lepoglava, 2006., 62-69.

17/ Gustav PIASEK, „Prilog povijesti franjevačke ljekarne u Varaždinu“, Farmaceutsko društvo Hrvatske, Farmaceutski glasnik, 37, Zagreb, 1981, 476-478.

18/ Gustav PIASEK i Martina PIASEK, „Varaždinsko zdravstvo u 17. stoljeću“, Institut za medicinska istraživanja Hrvatske akademije znanosti i umjetnosti u Zagrebu, Arhiv za higijenu rada i toksikologiju, 55, Zagreb, 2004, 25-34.

19/ Lujo PIHLER, „Stare varaždinske ljekarne i ljekarnici“, Farmaceutsko društvo Hrvatske, Farmaceutski glasnik, 7, Zagreb, 1951, 220-225, 269-277.

20/ Bernarda RATANČıć i Vladanka MILOŠEVIĆ, „Prilog poznavanju povijesti franjevačke ljekarne u Varaždinu“, Portal: godišnjak Hrvatskog restauratorskog zavoda, 7, Zagreb, 2016, 193-208.

21/ Mirjana REPANIĆ BRAUN, Barokno slikarstvo u Hrvatskoj franjevačkoj provinciji sv. Ćirila i Metoda, Institut za povijest umjetnosti, Zagreb, 2004.

22/ Hrvoje TARTALJA, „Freske Ivana Rangera u franjevačkoj ljekarni u Varaždinu“, Pliva, Saopćenja, 12, Zagreb, 1969., 85-90.

23/ Božidar TOMAŠıć, Ljekarništvo u franjevačkom samostanima Provincije svetih Ćirila i Metoda - V, url: http://www.hdft.hr/ljekarnistvo-u-franjevackimsamostanima-provincije-svetih-cirila-i-metodija/ (14. veljače 2014.) 


\section{SAŽETAK \\ NOVE KONZERVATORSKE SPOZNAJE O OSLIKANOJ FRANJEVAČKOJ LJEKARNI U VARAŽDINU}

Zgrada varaždinskog franjevačkog nemoćišta podignuta je 1667. godine uz zapadno samostansko krilo, a u njezinu sastavu djelovala je ljekarna koja je opsluživala potrebe franjevaca, ali i čitavoga grada. Sredinom 18. stoljeća nemoćište i ljekarna su doživjeli veliku obnovu pri čemu je svod najveće prostorije prizemlja oslikao znameniti pavlinski slikar Ivan Krstitelj Ranger. Uslijed neadekvatnog korištenja prostora i pojave kapilarne vlage, oslik je u dvadesetom stoljeću bio dosta oštećen. Raniji pokušaji sanacije vlage iz raznih su razloga prekinuti, zbog čega problemi vlage i kristalizacije soli nisu riješeni što je uzrokovalo ubrzano propadanje slikanoga sloja.

Kritično stanje oslika potaknulo je uključivanje Hrvatskog restauratorskog zavoda 2013. godine, kada su provedena prva konzervatorsko-restauratorska istraživanja. U prostoriji bivše ljekarne utvrđena je vrlo nepovoljna mikroklimatska situacija, a kao glavni izvori problema utvrđeni su mokri riječni agregat betonskog poda, zazidano i nesanirano staro ložište otkriveno u hodniku prizemlja te cementna površinska žbuka i akvatril premaz, naneseni tijekom ranijih zahvata. Provedeni su radovi uklanjanja svih izvora štetnih utjecaja, što je uključivalo: uklanjanje betonskog poda u ljekarni i izvedba novoga, otvaranje i čišćenje ložišta i vertikale dimnjaka i obijanje cementne žbuke i akvatrila sa zidova podruma i prizemlja. To je omogućilo uvid u zidane strukture zgrade i utvrđivanje triju građevinskih ili oblikovnih faza. lako su provedena istraživanja i pripremni radovi za sada parcijalni, učinjen je velik pomak prema stvaranju povoljnih uvjeta za restauratorske radove na svodnoj slici i u konačnici njezina prezentacija.

Ključne riječi: Franjevačka ljekarna; franjevci u Varaždinu; barokno slikarstvo; Ivan Krstitelj Ranger; restauratorsko-konzervatorska istraživanja. 


\section{SUMMARY \\ NEW CONSERVATION INSIGHTS ABOUT THE FRESCO-PAINTED PHARMACY IN VARAŽDIN}

The Varaždin Franciscan infirmary was built in 1667, adjacent to the western wing of the Franciscan Monastery. It included a pharmacy which was used, not only by the monks, but also by the people of the entire town. The infirmary and the pharmacy were thoroughly restored in the mid-18 ${ }^{\text {th }}$ century, when the renowned Pauline painter, John the Baptist Ranger, painted the vault of the biggest ground-floor room. Unfortunately, due to inadequate space usage and capillary rising damp, the frescoes were quite damaged in the $20^{\text {th }}$ century. For various reasons, all preceding attempts of sanation had been terminated, leaving the issues of damp and salt cristallization unresolved, which led to rapid deterioration of the painted layer.

In 2013, Croatian Conservation Institute was included in the issue, because of the severe state of the frescoes. That was when initial conservation and restoration research was conducted. It was found that the microclimatic conditions in the former pharmacy were extremely poor, mainly due to several factors: wet aggregate of concrete floors, a walled-in furnace, which was found damaged in the hallway of the ground floor, and the surface cement plaster and waterproof coat Aquathrill, which had been applied in previous interventions. The work conducted by the Conservation Institute included the removal of all sources of damage: the concrete floor in the pharmacy was replaced with a new one, the furnace and chimney flue were opened and cleaned, and the cement plaster and Aquathrill were removed from the walls in the basement and ground floor. This enabled clear insight into the wall structures of the building and defining three phases of construction. Even though the conducted research and preliminary work are still partial, a big step has been made towards creating beneficial conditions for restoration work on the vault painting, and, ultimately, its presentation.

Key Words: Franciscan pharmacy; Franciscans in Varaždin; baroque painting; John the Baptist Ranger; restoration-conservation research. 